\title{
Effect of Pumpkin Flour on the Rheological Characteristics of Wheat Flour and on Biscuit Quality
}

\author{
Khan MA*, Mahesh C, Vineeta P, Sharma GK, Semwal AD \\ Defence Food Research Laboratory, Siddartha Nagar, Mysore -570011, India
}

\begin{abstract}
Effect of pumpkin flour on the physico-chemical, rheological, nutritional and sensory characteristics on biscuits was studied by incorporating pumpkin flour at different concentrations from $5-25 \%$ based on refined wheat flour (Maida). Addition of $15 \%$ of pumpkin flour was found to be optimum for biscuit preparation. Effect of incorporation of pumpkin flour had a significant $(\mathrm{p} \leq 0.05)$ effect on rheological characteristics of wheat flour studied by using mixograph, alevo-consistograph and rapid visco analyser etc. During storage, the chemical changes and overall acceptability scores were found to be negatively correlated $(r<-0.97)$.
\end{abstract}

Keywords: Alveograph; Falling number; Colour; Sensory; Texture; Carotenoids

\section{INTRODUCTION}

Pumpkin a tropical and subtropical growing vegetable occupies a permanent place due to its high productivity, nutritive value and long period of availability. Its nutritive value varies from one species to another. It is rich in $\beta$-carotene, a precursor of Vitamin ' $A$ ' and helps in the prevention of various ailments/diseases like eye disorder, cancer and skin related problems. It acts as sedative, refrigerant, diuretic and quenches thirst [1-4]. Fresh pumpkin fruit which can be consumed as freshly boiled and steamed or as processed food items such as soup or curry is very perishable and sensitive to microbial spoilage due to its high moisture content. Different drying techniques are widely used for preservation constituting an alternative to the consumption of fresh fruits and vegetables and allowing their use during off season [5].

In India, baking Industry is considered as one of the major segments of food processing sector. Baked products in the form of biscuits and cookies are gaining popularity as they offer certain advantages like availability, ready to eat convenience, cheaper than conventional snack items, availability in varieties and shelf life [6]. Though in India per capita consumption of biscuits is low as compared to developed countries, but during last decade, per capita consumption has doubled [7]. Biscuits are ideal for nutrient availability, palatability, compactness and convenience. With the changing life style, consumers demands foods with multiple health benefits resulting in the developments of new processing technologies in food nutrition science. The present day scenario demands using of novel ingredients in commonly consumed foods rather than developing new products to improve the functional characteristics [8]. So many ignored crops which are rich source of phytochemicals of human interest for combating the deadly diseases like cancer and cardiovascular diseases are used in the development of various food products $[9,10]$. Earlier workers have reported use of protein rich ingredients like oil seed meals, pulses and industrial by-products like wheat germ and milk products to improve the nutritional quality of biscuits [11-14]. Pumpkin is gaining popularity as its technological and nutritional characteristics are equal or even better than those of widely cultivated vegetables and fruits. Pumpkin is consumed in a variety of ways such as fresh or cooked as well as being stored, frozen or canned [15] but in India it is mostly consumed as fresh vegetable and only a limited part goes for candy, preserve and sweets making and holds a vast potential in the manufacture of value added products. Earlier studies on the effect of dried pumpkins in wheat bread production reported an increase in reducing sugar, vitamin $\mathrm{c}$ and carotenoids with the increase in pumpkin powder [16]. Development of cake using pumpkin powder showed that use of more than $10 \%$ of pumpkin powder had strong effects on physico-chemical and organoleptic properties of cake [17]. Effect of replacement of refined wheat flour with pumpkin powder on the textural and sensory qualities of bakery products was evaluated and reported that pumpkin powder could be very well utilised to prepare the bakery products [18]. Though literature is available on the development of various bakery products using pumpkin flour but literature is scanty on the use of pumpkin flour in the preparation of biscuits and its effect on physico-chemical, rheological, textural, sensory attributes and also storage studies of biscuits prepared by incorporating pumpkin flour. Therefore

Correspondence to: Khan MA, Defence Food Research Laboratory, Siddartha Nagar, Mysore -570011, India, E-mail: abulzodfrl@gmail.com

Received: October 4, 2019; Accepted: October 22, 2019; Published: October 30, 2019

Citation: Khan MA, Mahesh C, Vineeta P, Sharma GK, Semwal AD (2019) Effect of Pumpkin Flour on the Rheological Characteristics of Wheat Flour and on Biscuit Quality Flours. J Food Process Technol 10:814. doi: 10.35248/2157-7110.19.10.814

Copyright: (C2019 Khan MA, et al. This is an open-access article distributed under the terms of the Creative Commons Attribution License, which permits unrestricted use, distribution, and reproduction in any medium, provided the original author and source are credited. 
attempts were made to evaluate the effect of incorporation of pumpkin flour and development of biscuits.

\section{MATERIALS AND METHODS}

Wheat flour, sugar powder, shortening (Bunge India Pvt. Ltd., Mumbai, India), skimmed milk powder (Nandini brand), vanilla essence (Bush Boake Allen Ltd., Chennai, India), mature pumpkin were procured from the local market. Sodium bicarbonate and ammonium bicarbonate were procured from $\mathrm{M} / \mathrm{s}$ SD Fine chemicals, Mumbai and Dextrose from M/s Rankem, New Delhi.

\section{Preparation of pumpkin powder}

Pumpkin procured from the local market was peeled, deseeded to separate the edible portion and washed in tap water to remove the impurities. Trimmed pumpkin was grated and blanched at $90^{\circ} \mathrm{C}$ for $2-3$ min with $500 \mathrm{ppm}$ of potassium meta-bisulphite and dried in a fluidised bed dryer at $70^{\circ} \mathrm{C}$ for $4 \mathrm{hrs}$ to get desired moisture content of $5-6 \%$. The dried pumpkin was grounded, sieved and stored at ambient temperature conditions in sealed metallised polyester pouches for further use.

\section{Physico-chemical analysis}

Moisture, protein, total ash, crude fibre and total fat contents were determined by standard methods [19]. Total carotenoid content was estimated according to the method prescribed by Ranganna [20] using hexane-acetone solvent mixture by titrometry method. Properties like thickness, diameter and spread ratio of biscuits were determined as per the method described by Anu et al. [21]. Spread ratio of biscuits was obtained by dividing diameter by thickness of the biscuits.

\section{Texture measurement}

Effect of pumpkin flour on the textural characteristics of biscuits viz hardness and breaking strength was evaluated using Texture Analyzer (Stable Microsystems, UK, Model TAHD) in a compression mode using a sharp blade cutting probe. Pre-test, test and post-test speeds were $1.5 \mathrm{~mm} / \mathrm{sec}, 2 \mathrm{~mm} / \mathrm{sec}$ and $10 \mathrm{~mm} / \mathrm{sec}$ respectively. The peak force from the resulting curve indicated as the breaking strength of the biscuits.

\section{Color measurements}

The color measurement of biscuits prepared using pumkin flour was carried out using a Hunter Colorimeter fitted with optical sensor (Mini Scan XE Plus, Model 45/0-S, Hunter Associates Laboratory Inc, Reston, VA, USA) on the basis of CIE L*, a*, ${ }^{*}$ color system. $L^{*}$ values measure black to white $(0-100)$, a values measure redness when positive, and $b^{*}$ values measure yellowness when positive.

\section{Rheological characteristics}

Effect of pumpkin flour on the alveo-consistographic tests of refined wheat flour like water absorption, dough development time (Tpr), tenacity $(\mathrm{P})$, dough extensibility (L) and the deformation energy (W) were conducted using Alveograph (Alveolink NG Consistograph; Villeneuve La Garenne, Chopin, France) following the approved methods [22]. The mixing characteristics were measured by using the $10 \mathrm{~g}$ moving mixograph (National MFG, Division, TMCO, Lincoln, USA). Rapid Visco Analyser 4D (Newport Scientific Pvt Ltd, Warie Wood, Australia) was used to measure pasting properties of flours as described by approved method [22]. The $\alpha$-amylase activity and gluten content of the mixes was determined using Falling number (M/s Perten Instruments Pvt Ltd) and Gluten analyser (M/s LCGC Instruments) according the approved method [22].

\section{RESULT AND DISCUSSION}

Pumpkin flour had moisture 5.5\%; ash 5.5\%; protein 3.25\%; crude fibre $5.0 \%$; fat $1.48 \%$, carotenoids $612.1 \mathrm{mg} / 100 \mathrm{~g}$; total sugar $36.17 \%$; reducing sugar $24.57 \%$ and vitamin $C$ content of $21.16 \mathrm{mg} / 100 \mathrm{~g}$. Proximate composition of biscuits prepared by using pumpkin flour $(5-25 \%)$ is given in Table 1 . It is evident that incorporation of pumpkin flour resulted in linear increase in moisture content from 3.52 to 3.69. This may be attributed to the high water binding capacity of pumpkin powder which retained higher moisture content in biscuits [23]. Incorporation of pumpkin flour has resulted decrease in protein content from 7.23 to $6.54 \%$ and increase in fat content from 13.34 to 14.10 ; ash content 0.56 to $1.28 \%$ and fibre 0.35 to $1.86 \%$. Incorporation of pumpkin flour also resulted in an increase in carotenoids and vitamin c contents in biscuits.

\section{Effect of pumpkin flour on the physical properties and textural attributes of biscuits}

Biscuits prepared using pumpkin flour $(0-25) \%$ was evaluated for various physical parameters viz diameter, thickness, spread ratio and breaking strength (Table 2). It is clear from the table that with the increase in pumpkin flour (5-25\%), there was a significant increase $(p \leq 0.05)$ in breaking strength and thickness and decrease in spread ratio. Breaking strength was found to be increased from 13.43 to $20.76 \mathrm{~N}$, thicknesses from 0.53 to $0.65 \mathrm{~mm}$ whereas diameter decreased from $5.6 \mathrm{~mm}$ to $5.44 \mathrm{~mm}$ and spread ratio from 9.54 to 7.0 . The changes in physical properties may be due to

Table 1: Proximate composition of pumpkin flour incorporated biscuits.

\begin{tabular}{|c|c|c|c|c|c|c|c|c|c|}
\hline $\begin{array}{c}\text { Pumpkin Flour } \\
\text { Concentration (\%) }\end{array}$ & $\begin{array}{l}\text { Moisture* } \\
(\%)\end{array}$ & Ash (\%)* & Protein* (\%) & $\begin{array}{c}\text { Total Fat } \\
(\%)^{*}\end{array}$ & Fibre $(\%)^{*}$ & $\begin{array}{c}\text { Carbohydrates } \\
(\%)^{*}\end{array}$ & $\begin{array}{c}\text { Carotenoids } \\
(\mu \mathrm{g} / \mathrm{g})^{*}\end{array}$ & $\begin{array}{l}\text { Total sugars } \\
(9 \%)^{*}\end{array}$ & $\begin{array}{l}\text { Reducing } \\
\text { sugars }(\%)^{*}\end{array}$ \\
\hline Control (0\%) & $3.52 \pm 0.02^{\mathrm{a}}$ & $0.56 \pm 0.01^{\mathrm{a}}$ & $7.23 \pm 0.08^{\mathrm{a}}$ & $13.34 \pm 0.10^{a}$ & $0.82 \pm 0.06$ & $74.56 \pm 0.25$ & - & $16.9 \pm 0.13$ & $1.69 \pm 0.01$ \\
\hline $5 \%$ & $3.61 \pm 0.02^{b}$ & $0.62 \pm 0.02^{b}$ & $7.10 \pm 0.05^{\mathrm{b}}$ & $13.50 \pm 0.11^{b}$ & $0.92 \pm 0.05$ & $74.24 \pm 0.31$ & $6.51 \pm 0.10$ & $19.35 \pm 0.15$ & $2.13 \pm 0.02$ \\
\hline $10 \%$ & $3.62 \pm 0.01^{b}$ & $0.77 \pm 0.03^{c}$ & $7.03 \pm 0.09^{b}$ & $13.65 \pm 0.13^{c}$ & $0.98 \pm 0.04$ & $73.06 \pm 0.29$ & $10.39 \pm 0.11$ & $19.42 \pm 0.14$ & $2.34 \pm 0.03$ \\
\hline $15 \%$ & $3.65 \pm 0.02^{c}$ & $0.81 \pm 0.04^{\mathrm{d}}$ & $6.85 \pm 0.08^{c}$ & $13.88 \pm 0.12^{\mathrm{d}}$ & $1.36 \pm 0.05$ & $73.45 \pm 0.26$ & $16.17 \pm 0.10$ & $19.74 \pm 0.16$ & $2.59 \pm 0.03$ \\
\hline $20 \%$ & $3.66 \pm 0.03^{c}$ & $0.98 \pm 0.03^{e}$ & $6.76 \pm 0.05^{\mathrm{d}}$ & $13.96 \pm 0.13$ & $1.58 \pm 0.04$ & $73.06 \pm 0.56$ & $17.16 \pm 0.14$ & $20.24 \pm 0.15$ & $3.12 \pm 0.02$ \\
\hline
\end{tabular}

"Mean \pm SD $(n=3)$

${ }^{\text {aff }}$ Values within the same column followed by different superscripts differ significantly $(\mathrm{p} \leq 0.05)$ 
the higher water holding capacity of pumpkin flour and also better binding strength of pumpkin flour protein [24].

\section{Effect of pumpkin flour on the colour values of biscuits}

Color measurements provide a useful index to evaluate the intensity of browning reactions and have been used to monitor the processing of biscuits. Effect of pumpkin flour on the colour values of biscuits was recorded using Hunter Colour Meter and the results are given in Table 3 . In the present study the $L^{*}$ value of pumpkin incorporated biscuits decreased while $a^{*}$ and $b^{*}$ value increased with increased proportion of pumpkin flour (Table 3). The decrease in lightness and increase in redness and yellowness in biscuits with the increase in concentration of pumpkin flour may be attributed to the fact that pumpkin flour had darker colour and more yellowness which is due to the presence of carotenoids. Earlier workers also reported decrease in lightness and increase in yellowness of food products prepared using pumpkin flour [25]. The decreased $L^{*}$ values and increased $a^{*}$ and $b^{*}$ values resulted in darkening of the biscuits, which ultimately affected the sensory scores for colour.

\section{Effect of pumpkin flour on the sensory quality of biscuits}

Effect of pumpkin flour on the sensory quality of biscuits was carried out to find out the suitability and level of incorporation of pumpkin flour in wheat flour (Table 3). It is evident from the table that addition of pumpkin flour upto $15 \%$ has improved the acceptability of biscuits and further increase in the concentration has adversely affected the texture, colour and overall acceptability. It is therefore concluded that highly acceptable biscuits can be prepared using 15\% pumpkin flour and addition of beyond 15\% levels of pumpkin flour significantly reduced the overall acceptance of the biscuits.

\section{Effect of pumpkin powder on the alveo-consistographic characteristics of wheat flour}

Effect of pumpkin powder on the alveo-consistographic characteristics of wheat flour is shown in Table 4. It is observed that there was an increase in water absorption (WA) from $59.0 \%$ to $68.45 \%$ with the increase in pumpkin flour $(5-25 \%)$. The increase in water absorption may be due to the presence of hydroxyl groups

Table 2: Effect of pumpkin flour on the physical and textural attributes of biscuits.

\begin{tabular}{cccccc}
\hline \multirow{2}{*}{$\begin{array}{c}\text { Pumpkin Flour } \\
\text { Concentration }(\%)\end{array}$} & \multicolumn{3}{c}{ Physical properties } & \multicolumn{2}{c}{ Textural properties } \\
\cline { 2 - 6 } & Thickness $(\mathbf{c m})^{*}$ & Diameter $(\mathrm{cm})^{*}$ & Spread ratio $^{*}$ & Hardness (N) $^{*}$ & Breaking strength (N) $^{*}$ \\
\hline Control & $0.53 \pm 0.01^{\mathrm{a}}$ & $5.62 \pm 0.2^{\mathrm{a}}$ & $10.6^{\mathrm{a}}$ & $9.81 \pm 0.4^{\mathrm{a}}$ & $11.10 \pm 0.6^{\mathrm{a}}$ \\
\hline $5 \%$ & $0.59 \pm 0.03^{\mathrm{b}}$ & $5.5 \pm 01^{\mathrm{b}}$ & $9.32^{\mathrm{b}}$ & $11.25 \pm 0.5^{\mathrm{b}}$ & $13.15 \pm 0.8^{\mathrm{b}}$ \\
\hline $10 \%$ & $0.66 \pm 0.02^{\mathrm{c}}$ & $5.39 \pm 0.1^{\mathrm{c}}$ & $8.17^{\mathrm{c}}$ & $13.85 \pm 0.5^{\mathrm{c}}$ & $16.26 \pm 0.9^{\mathrm{c}}$ \\
\hline $15 \%$ & $0.73 \pm 0.03^{\mathrm{d}}$ & $5.31 \pm 0.1^{\mathrm{c}}$ & $7.27^{\mathrm{d}}$ & $14.49 \pm 0.7^{\mathrm{d}}$ & $20.76 \pm 1.2^{\mathrm{d}}$ \\
\hline $20 \%$ & $0.80 \pm 0.01^{\mathrm{e}}$ & $5.28 \pm 0.2^{\mathrm{d}}$ & $6.60^{\mathrm{e}}$ & $17.24 \pm 0.9^{\mathrm{e}}$ & $23.45 \pm 1.4^{\mathrm{e}}$ \\
\hline $25 \%$ & $0.92 \pm 0.04^{\mathrm{f}}$ & $5.06 \pm 0.2^{\mathrm{e}}$ & $5.50^{\mathrm{f}}$ & $22.46 \pm 1.4^{\mathrm{f}}$ & $28.65 \pm 1.5^{\mathrm{f}}$ \\
\hline
\end{tabular}

${ }^{*}$ Mean $\pm \mathrm{SD}(\mathrm{n}=3)$

a-F Values within the same column followed by different superscripts differ significantly ( $\mathrm{p} \leq 0.05)$

Table 3: Effect of pumpkin flour on the colour values (Hunter) and sensory attributes of biscuits.

\begin{tabular}{cccccc}
\hline Pumpkin Flour Concentration (\%) & Lightness $(\mathrm{L})^{*}$ & Redness $(\mathrm{a})^{*}$ & ${\text { Yellowness }(\mathrm{b})^{*}}^{{ }^{*}}$ & Taste $^{* *}$ & OAA $^{* *}$ \\
\hline Control (0\%) & $56.81 \pm 0.7^{\mathrm{a}}$ & $7.33 \pm 0.1^{\mathrm{a}}$ & $26.96 \pm 0.5^{\mathrm{a}}$ & $8.5 \pm 0.1^{\mathrm{a}}$ & $8.5 \pm 0.1^{\mathrm{a}}$ \\
\hline $5 \%$ & $54.64 \pm 0.6^{\mathrm{b}}$ & $10.09 \pm 0.2^{\mathrm{b}}$ & $28.67 \pm 0.8^{\mathrm{b}}$ & $8.2^{\mathrm{b}} \pm 0.2^{\mathrm{b}}$ & $8.3 \pm 0.1^{\mathrm{b}}$ \\
\hline $10 \%$ & $51.09 \pm 0.6^{\mathrm{c}}$ & $10.84 \pm 0.1^{\mathrm{c}}$ & $32.33 \pm 0.4^{\mathrm{c}}$ & $8.1 \pm 0.2^{\mathrm{c}}$ & $8.1^{\mathrm{b}} \pm 0.2^{\mathrm{c}}$ \\
\hline $15 \%$ & $48.74 \pm 0.4^{\mathrm{d}}$ & $11.19 \pm 0.3^{\mathrm{d}}$ & $35.66 \pm 0.6^{\mathrm{d}}$ & $8.0 \pm 0.1^{\mathrm{c}}$ & $8.0 \pm 0.1^{\mathrm{c}}$ \\
\hline $20 \%$ & $44.71 \pm 0.4^{\mathrm{e}}$ & $12.45 \pm 0.2^{\mathrm{e}}$ & $38.43 \pm 0.5^{\mathrm{e}}$ & $7.0 \pm 0.2^{\mathrm{d}}$ & $7.0 \pm 0.3^{\mathrm{d}}$ \\
\hline $25 \%$ & $40.08 \pm 0.3^{\mathrm{f}}$ & $16.55 \pm 0.1^{\mathrm{f}}$ & $40.98 \pm 0.5^{\mathrm{f}}$ & $6.5 \pm 0.1^{\mathrm{e}}$ & $6.4 \pm 0.1^{\mathrm{e}}$ \\
\hline
\end{tabular}

${ }^{*}$ Mean $\pm \mathrm{SD}(\mathrm{n}=3)$

${ }^{* *}$ Mean $\pm \mathrm{SD}(\mathrm{n}=15)$

${ }^{a f}$ Values within the same column followed by different superscripts differ significantly $(\mathrm{p} \leq 0.05)$

Table 4: Effect of pumpkin flour on the alveo-consisto-graphic characteristics, gluten content (wet and Dry) and falling number of wheat flour.

\begin{tabular}{|c|c|c|c|c|c|c|c|c|}
\hline \multirow{2}{*}{ Pumpkin Flour Concentration (\%) - } & \multicolumn{5}{|c|}{ Alveo-consistograph characteristics } & \multicolumn{2}{|c|}{ Gluten $(\%)^{*}$} & \multirow{2}{*}{ Falling Number ( Sec) } \\
\hline & $\operatorname{TPr}$ & To1 & $\mathrm{P}$ & $\mathrm{L}$ & $\mathrm{W}$ & Wet gluten & Dry gluten & \\
\hline Control (0\%) & $154 \pm 5^{\mathrm{a}}$ & $319 \pm 6^{a}$ & $120 \pm 4^{a}$ & $40 \pm 1.2^{\mathrm{a}}$ & $165 \pm 4^{a}$ & $23.39 \pm 0.8^{\mathrm{a}}$ & $9.88 \pm 0.2^{\mathrm{a}}$ & $412 \pm 7^{a}$ \\
\hline $5 \%$ & $172 \pm 8^{\mathrm{b}}$ & $285 \pm 5^{b}$ & $125 \pm 5^{b}$ & $35 \pm 1^{\mathrm{b}}$ & $155 \pm 5^{b}$ & $21.21 \pm 0.6^{\mathrm{b}}$ & $9.25 \pm 0.3^{b}$ & $394 \pm 5^{b}$ \\
\hline $10 \%$ & $184 \pm 6^{c}$ & $234 \pm 4^{c}$ & $140 \pm 4^{c}$ & $29 \pm 0.9^{c}$ & $147 \pm 4^{c}$ & $17.82 \pm 0.5^{c}$ & $8.77 \pm 0.3^{c}$ & $373 \pm 7^{c}$ \\
\hline $15 \%$ & $311 \pm 6^{\mathrm{d}}$ & $174 \pm 6^{\mathrm{d}}$ & $151 \pm 5^{\mathrm{d}}$ & $24 \pm 0.85 d$ & $135 \pm 5^{\mathrm{d}}$ & $13.12 \pm 0.4^{\mathrm{d}}$ & $8.15 \pm 0.2^{\mathrm{d}}$ & $336 \pm 6^{\mathrm{d}}$ \\
\hline $20 \%$ & $211 \pm 5^{\mathrm{e}}$ & $174 \pm 5^{\mathrm{e}}$ & $160 \pm 4 \mathrm{e}$ & $19 \pm 0.74^{\mathrm{e}}$ & $120 \pm 4^{e}$ & $10.14 \pm 0.4^{\mathrm{e}}$ & $6.82 \pm 0.2^{\mathrm{e}}$ & $281 \pm 7^{\mathrm{e}}$ \\
\hline $25 \%$ & $320 \pm 7^{f}$ & $142 \pm 5^{f}$ & $167 \pm 4^{f}$ & $11 \pm 0.7^{f}$ & $109 \pm 5^{\mathrm{f}}$ & $8.19 \pm 0.3^{f}$ & $5.72 \pm 0.1^{\mathrm{f}}$ & $234 \pm 5^{f}$ \\
\hline
\end{tabular}

"Mean \pm SD $(n=3)$

${ }^{a \cdot f}$ Values within the same column followed by different superscripts differ significantly $(\mathrm{p} \leq 0.05)$ 
in the fibre which allow more water interaction through hydrogen bonding. Earlier it was also reported [26] an increase in water absorption with the increase in pumpkin flour using Farinograph. Earlier workers also reported that addition of fiber increases water absorption in cookies and bread due to hydroxyl groups present in the fiber [27-29]. The time required for dough development to reach a dough consistency equivalent to $2,200 \mathrm{mb}$ pressure (TPr) was increased from 154 to $320 \mathrm{sec}$. The increase in dough development time due to the decrease in the dough strength with the increase in fiber content owning to dilution and disruption of continuity of gluten $[13,27,29]$. It was found that with the increase in pumpkin powder there was a decrease in tolerance, which measures the stability of the dough from 319 to $142 \mathrm{sec}$.

Parameters viz tenacity $(\mathrm{P})$ which measures handling characteristics of the dough capacity, the extensibility (L) characteristics of dough and baking strength (W) were studied using alveograph. It is observed from the table that with the increase in pumpkin powder there was an increase in tenacity (P) from 120 to $178 \mathrm{~mm}$, while extensibility of the dough (L) decreases from $40 \mathrm{~mm}$ to $14 \mathrm{~mm}$. The baking strength (W) was found to decrease from 165 to 120J. The changes in Alveograph characteristics with the increase in pumpkin flour are may be due to partial disruption of gluten and also attributed to the interactions between the fiber structure and wheat proteins.

\section{Effect of pumpkin powder on the pasting properties of wheat flour}

Effect of pumpkin powder on the pasting properties of wheat flour is shown in Table 5. It is clear from the table that increase in the pumpkin flour concentration resulted in the decrease in peak viscosity, which relates to the ability of starch granules to swell freely before their physical break down decreases from 150 to 101 RVU. Earlier also a decrease in peak viscosity with the increase in rice bran and Moringa leaves concentrations respectively was reported [30]. Susceptibility of cooked starch granules to disintegration is measured by break down viscosity and is highly influenced by the amylase content which decreases from 50.12 to 38.19 RVU. The set-back viscosity which is a measure of the recrystallization of gelatinised starch during cooking and also represents the effect of cooking and tendency to retrograde decreases significantly from 65.25 to $39.23 \mathrm{RVU}$. The changes in viscosities due to the incorporation of pumpkin flour may be attributed to the partial gelatinisation of starch and denaturation of proteins and less water available for initial swelling of starch granules. The aggregation of amylase fractions also resulted in the changes in pasting properties of wheat flour incorporated with pumpkin flour.

\section{Effect of pumpkin powder on the mixographic characteristics of wheat flour}

Figure 1 shows the effect of pumpkin powder on the mixographic characteristics of wheat flour. It is observed that with the increase in pumpkin flour concentration there was an increase in peak time which measures the time taken for dough development from 4.60 to 7.24 . The increase in mixing time is a result of toughening effect of gluten due to the presence of fibre content in pumpkin flour. The similar trend was observed by earlier authors. The ascending and descending slopes were found to get affected by the addition of pumpkin powder.

Table 5: Effect of pumpkin flour on the pasting properties of wheat flour.

\begin{tabular}{cccc}
\hline \multirow{2}{*}{$\begin{array}{c}\text { Pumpkin Flour } \\
\text { Concentration (\%) }\end{array}$} & \multicolumn{3}{c}{ Pasting properties } \\
\cline { 2 - 4 } & Peak viscosity & Break down & Set back \\
\hline Control (0\%) & $154 \pm 7^{\mathrm{a}}$ & $319 \pm 8^{\mathrm{a}}$ & $120 \pm 5^{\mathrm{a}}$ \\
\hline $5 \%$ & $172 \pm 8^{\mathrm{b}}$ & $285 \pm 7^{\mathrm{b}}$ & $125 \pm 3^{\mathrm{b}}$ \\
\hline $10 \%$ & $184 \pm 5^{\mathrm{c}}$ & $234 \pm 7^{\mathrm{c}}$ & $140 \pm 5^{\mathrm{c}}$ \\
\hline $15 \%$ & $311 \pm 7^{\mathrm{d}}$ & $174 \pm 5^{\mathrm{d}}$ & $160 \pm 4^{\mathrm{d}}$ \\
\hline $20 \%$ & $211 \pm 6^{\mathrm{e}}$ & $160 \pm 6^{\mathrm{e}}$ & $171 \pm 5^{\mathrm{e}}$ \\
\hline $25 \%$ & $320 \pm 10^{\mathrm{f}}$ & $142 \pm 5^{\mathrm{f}}$ & $184 \pm 5^{\mathrm{f}}$ \\
\hline
\end{tabular}

"Mean \pm SD $(n=3)$

a-F Values within the same column followed by different superscripts differ significantly $(\mathrm{p} \leq 0.05)$
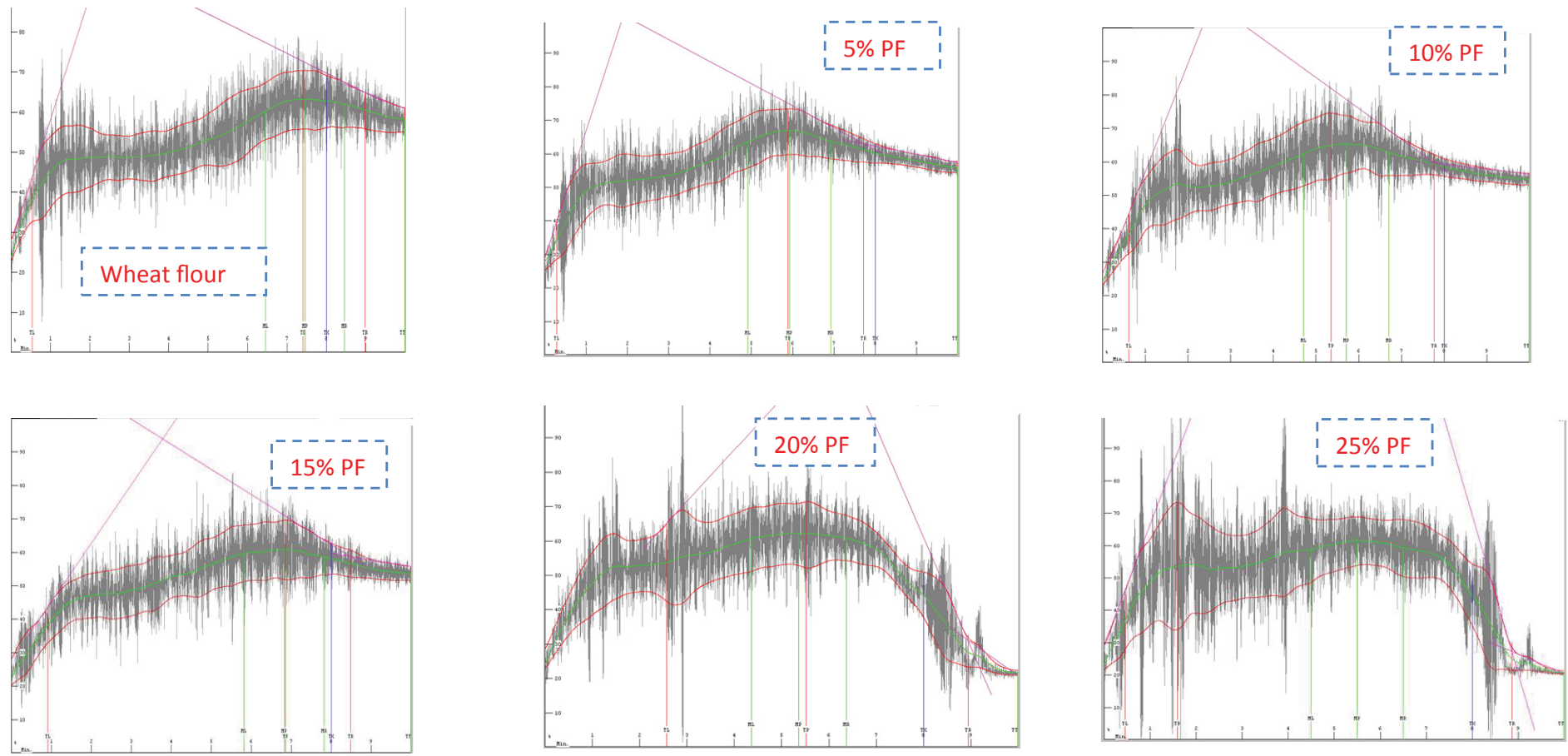

Figure 1: Effect of pumpkin flour $(\mathrm{PF})$ on the mixographic characteristics of wheat flour. 


\section{Effect of pumpkin flour on the gluten content and falling number of wheat flour}

The changes in gluten content of both wet and dried form of wheat flour incorporated with pumpkin flour (0-25\%) was carried out by using gluten analyser and the results obtained are shown in Table 4. It was observed that with the increase in pumpkin flour, there was a decrease in both wet and dried gluten content. Wet gluten was found to decrease from $23.39 \%$ to $7.19 \%$ and dry gluten decreased from $9.88 \%$ to $5.72 \%$. Falling number which measures the presence of amylase activity in the wheat flour found to decrease from 462 to $315 \mathrm{sec}$ with the increase in pumpkin flour concentration.

\section{Storage studies of pumpkin incorporated biscuits}

Biscuits prepared using 15\% of pumpkin flour (standardised) were packed in Polypropylene (PP) and metallised polyester (MP) packaging materials and stored at ambient temperature conditions for further storage studies. Initially and at a regular interval of 10 days biscuits were analysed for different physico-chemical parameters like moisture, peroxide value (PV), free fatty acid value (FFA), thiobarbituric acid value (TBA) and sensory attributes (OAA). It was found that during storage there were no significant changes in moisture content upto 2 months. But after 2 months there was a slight increase in moisture content both in PP and MP packed samples. But the significant increase was found in samples packed in PP packaging materials. However, there was no sogginess was found in biscuits irrespective of packaging materials. Lipid peroxidation was measured by analysing parameters like peroxide value, thiobarbituric acid value and free fatty acid values. It may be observed that the rate of autoxidation as measured by changes in PV and TBA values were higher in samples packed in $\mathrm{PP}$ as compared to those in MP packed ones. The peroxide value of biscuits packed in PP increased from 5.12 to 8.60 meq $\mathrm{O}_{2} / \mathrm{kg}$ fat as compared to 5.12 to $6.81 \mathrm{meq} \mathrm{O}_{2} / \mathrm{kg}$ for those packed in MP at the end of 4 months of storage. The TBA values after 4 months of storage increased from 0.051 to 0.067 and 0.051 to $0.058 \mathrm{mg}$ malonaldehyde/ $\mathrm{kg}$ in PP and MP packed samples respectively. FFA in biscuits increased during storage irrespective of the packaging materials used and the increase was considerably higher in PP as compared to MP packed samples. After 4 months of storage, the FFA value in PP packed samples was 0.57 compared to 0.52 as \% oleic acid in MP packed ones. Hydrolysis of lipids during storage is normally brought about by the naturally occur-ring lipases. However, during baking for preparation of biscuits, lipase activity was destroyed and therefore the formation of free fatty acids in stored biscuits might have resulted from the decomposition of hydroperoxide [31]. After 4 months of storage studies, since biscuits received least overall acceptability scores on a 9 point hedonic scale, studies were discarded [32].

\section{Correlation analysis}

The colour values ( $\mathrm{L}, \mathrm{a}, \mathrm{b})$ determined using hunter colorimeter, textural values (hardness and breaking strength) and physical parameters (spread ratio and thickness) had significant effect on the sensory quality of biscuits and also in determining the amount of pumpkin flour to be added in wheat flour to get highly acceptable biscuits. There was a negative correlation between lightness L, a and $b$ and OAA ( $r<-0.96,-0.95$ and -0.96). The correlation between hardness and OAA and Breaking strength and OAA were found to be -0.95 and -0.97 respectively. The negative correlation indicated that with the increase in hardness and breaking strength, the overall acceptability of biscuits decreased. Significant correlation ( $p$ $\leq 0.05$ ) was observed between the physical parameters like thickness and spread ratio and overall acceptability scores of biscuits. During storage, the chemical changes and overall acceptability scores were found to be negatively correlated $(r<-0.97)$. The correlation between PV and OAA, FFA and OAA and TBA \& OAA were found to be $-0.97,-0.97$ and -0.96 respectively. The negative correlation indicated that with the increase in PV, FFA and TBA, the overall acceptability of biscuits during storage decreased.

\section{CONCLUSION}

It is concluded from the discussion that it is feasible to produce biscuits with good nutritional value and sensory characteristics from pumpkin flour. Addition of pumpkin flour had a significant effect on rheological, textural and sensory characteristics of flour and biscuits prepared using refined wheat flour incorporated with pumpkin flour. Storage studies revealed that packaging materials played an important role in enhancing the shelf-life of biscuits.

\section{REFERENCES}

1. Bhat MA, Bhat A. Study on physico-chemical characteristics of pumpkin blended cake. J Food Process Technol. 2013;3:4-9.

2. Lee FA. Basic food chemistry. 1983 AVI Publisher, Westport.

3. Bendich A. Carotenoids and the immune response. J Nutrn. 1989;119:112-115.

4. Kirtikar KR, Basu BD. Indian medicinal plants. 1984;3:1664-1666.

5. Rakcejeva T, Galoburda R, Cude L, Strautniece E. Use of dried pumpkins in wheat production. Procedia Food Science. 2011;1:441-447.

6. Crassina A, Sheetal G, Venkateshwara RG. Effect of native and germinated finger millet flour on rheological and sensory characteristics of biscuits. Int J Food Sci Technol. 2012;47:2413-2420.

7. Ashwath KK, Sharma GK, Khan MA, Govindaraj T, Semwal AD. Development of multigrain premixes its effect on rheological, textural and micro-structural characteristics of dough and quality of biscuits. J Food Sci Technol. 2015;52:7759-7770.

8. Aleem ZMD, Genitha TR, Syed IS. Effects of defatted soy flour incorporation on physical, sensorial and nutritional roperties of biscuits. J Food Proc Technol. 2012;3:4.

9. Dhiman AK, Muzaffer S, Attri S. Utilisation of pumpkin (Cucurbita moschata) for product development. Him J Agric Res. 2007;33:223-227.

10. Dhiman AK, Muzaff S, Attri S. Functional constituents and processing of pumpkin: A review. J Food Sci Technol. 2009;40:411-417.

11. Sridevi SPL, Sarojini KS. Formulation of value added biscuits using defatted coconut flour. Am J Food Technol. 2013;8:207-212.

12. Jyotsna R, Shwetha J, Jyothilakshmi VRG. Influence of green gram flour (Phaseolus aureus) on the rheology, microstructure and quality of cookies. J Texture Studies. 2012;43:350-360.

13. Shivani B, Sudha ML. Nutritional, micro structural, rheological 
and quality characteristics of biscuits using processed wheat germination. Int J Food Sci Nutr. 2011; 62:474-479.

14. Santiago P, Elias M, Carlos O, Sanchez HM. Effect of soy flour and whey protein concentrates on cookie colour. LWT- Food Sci Technol. 2013;50:120-125.

15. Figueredo E, Cuesta HJ, Minguez A, Vidarte I, Pastor C. Allergy to pumpkin and cross reactivity to other cucurbitaceae fruits. J Allergy Clin Immunol. 2000;106:402-403.

16. Rakcejeva T, Galoburda R, Cude L, Strautniece E. Use of dried pumpkins in wheat production. Procedia Food Science. 2011;1:441-447.

17. Jesmin AM, Ruhul AM, Chandra MS. Effect of pumpkin powder on physic-chemical properties of cake. Int Res J of Biol Sci. 2016; 5:1-5.

18. Sudipta D, Soumitra B, Jayanti P. Utilization of foam mat dried pumpkin powder as a source of nutraceuticals content in cookies. Ann Food Sci Technol. 2015;16:338-346.

19. AOAC. Official methods of analysis of the Association of Official Analytical Chemists, 13th Edn. The Association, Washington, DC. 1980.

20. Ranganna S. Handbook of analysis and quality control for fruit and vegetable products. (2nd edn). Tata McGraw-Hill, New Delhi. 1986.

21. Anu B, Khalid G, Charanjit SR. Functional and sensory properties of cookies prepared from wheat flour supplemented with cassava and water chestnut flours. Cogent Food Agric. 2015;1:1019815.

22. AACC. Approved methods of the AACC, (10th edn). The Association, St. Paul MN. 2000.

23. Sunday YG, Dickson AD. Proximate composition and functional properties of raw and processed full fat fluted pumpkin (Telfairia occidentalia) seed flour. J Sci Food Agric. 1992;59:321-325.

24. Kumar P, Dorcus M, Chitra S. Development and quality evaluation of pumpkin powder fortified cookies. Int J Sci Eng Technol. 2015;3:1034-1038.

25. Seevaratnam V, Basumathi P, Premalatha M, Sundaram SM, Arumugam T. Studies on the preparation of biscuits incorporated with potato flour. World J Dairy Food Sci. 2012;7:79-84.

26. Wongsagonsup R, Kittisuban P, Yaowalak A, Suphantharika M. Physical and sensory qualities of composite wheat-pumpkin flour bread with addition of hydrocolloids. Int Food Res. 2015;22:745-752.

27. Pasha I, Qurratul ABK, Masood SB, Mohammed S. Rheological and functional properties of pumpkin wheat composite flour Pakistan. J Food Sci. 2013;23:100-104.

28. Khan MA, Mahesh C, Semwal AD, Sharma GK. Effect of spinach powder on physico-chemical, rheological, nutritional and sensory characteristics of chapati premixes. J Food Sci Technol. 2013;52:2359-2365.

29. Dachana KB, Jyotsna R, Indrani R, Jamuna P. Effect of dried Moringa (Moringa oleifera Lam) leaves on rheological, microbiological, nutritional, textural and organoleptic characteristics of cookies. J Food Qual. 2010 ;33:660-667.

30. Gomez M, Ronda F, Carlos A, Pedro B, Cballero A, Apesteguia A. Effect of dietary fiber on dough rheology and bread quality. Eur Food Res Technol. 2013;216:51-56.

31. Yadav DN, Patki PE, Sharma GK, Bawa AS. Effect of microwave heating of wheat grains on the browning of dough and quality of chapaties. Int. J Food Sci Technol. 2008: 43:1217-1225.

32. Thakur BR, Arya SS. Packaging requirement and stability of fried snacks (Trisnacks). J Food Sci Technol. 1990;27:76-81. 